\title{
Detection and identification of bacterial pathogens of fish in kidney tissue using terminal restriction fragment length polymorphism (T-RFLP) analysis of 16S rRNA genes
}

\author{
William B. Nilsson, Mark S. Strom* \\ Northwest Fisheries Science Center, National Marine Fisheries Service, National Oceanic and Atmospheric Administration, \\ United States Department of Commerce, 2725 Montlake Boulevard E., Seattle, Washington 98112, USA
}

\begin{abstract}
We report the application of a nucleic acid-based assay that enables direct detection and identification of bacterial pathogens in fish kidney tissue without the need for bacterial culture. The technique, known as terminal restriction fragment length polymorphism (T-RFLP), employs the polymerase chain reaction (PCR) using a primer pair that targets 2 highly conserved regions of the gene that encodes for the $16 \mathrm{~S}$ small subunit of the bacterial ribosome. Each primer is $5^{\prime}$ labeled with a different fluorescent dye, which results in each terminus of the resulting amplicon having a distinguishable fluorescent tag. The amplicon is then digested with a series of 6 restriction endonucleases, followed by size determination of the 2 labeled terminal fragments by capillary electrophoresis with laser-induced fluorescence detection. Comparison of the lengths of the full set of 12 terminal fragments with those predicted based on analyses of GenBank submissions of 16S sequences leads to presumptive identification of the pathogen to at least the genus, but more typically the species level. Results of T-RFLP analyses of genomic DNA from multiple strains of a number of fish bacterial pathogens are presented. The assay is further demonstrated on fish kidney tissue spiked with a known number of cells of Flavobacterium psychrophilum where a detection limit of ca. $30 \mathrm{CFU} \mathrm{mg}^{-1}$ of tissue was estimated. A similar detection limit was observed for several other Gram-negative pathogens. This procedure was also used to detect Aeromonas salmonicida and Renibacterium salmoninarum in the kidney tissue of 2 naturally infected salmonids.
\end{abstract}

KEY WORDS: Terminal restriction length polymorphism · T-RFLP · Bacteria · Universal detection · Bacterial pathogen identification

Resale or republication not permitted without written consent of the publisher

\section{INTRODUCTION}

The growing economic importance of the aquaculture industry worldwide has led to increasing interest in rapid and reliable methods for detection and identification of bacterial pathogens of fish. In recent years nucleic acid-based assays have received increased attention. These assays are generally stated to be more sensitive and more rapid to perform than those of a more conventional variety (e.g. biochemical and

*Corresponding author. E-mail: mark.strom@noaa.gov serological assays). Polymerase chain reaction (PCR)based assays have been developed for a wide variety of fish pathogens. All of the reported assays share a common characteristic in their use of primers designed to target genome sequences unique to either a genus, species or sometimes subspecies. In many cases, the target sequences may be a part of a gene that is itself unique to a given bacterial species. For example, several reported assays are specific for Renibacterium salmoninarum, the causative agent of bacterial kidney disease in salmonids (McIntosh et al. 1996, Chase \& Pascho 1998, Cook \& Lynch 1999). All 3 of these protocols use primers designed to amplify a portion of the 
msa gene that encodes the p57 protein, or so-called major soluble antigen, of $R$. salmoninarum. Similarly, primers targeting the surface array protein gene (vapA) in Aeromonas salmonicida were used by Gustafson et al. (1992) while assays for detection of $A$. hydrophila have been published that target the lipase H3 lip gene (Cascón et al. 1996) and the aer gene that encodes a $\beta$-hemolysin (Baloda et al. 1995). Primers targeting another hemolysin gene, vah1, were utilized in an assay for Vibrio anguillarum (Hirono et al. 1996). Bidinost et al. (1999) recently published primers designed to amplify a portion of repM, the structural gene whose function is replication of the cryptic plasmid pMJ101 carried by all known isolates of $V$. ordalii. Other published assays have used primers designed to target sequences from apparently noncoding (but nonetheless unique) regions of the bacterial genome such as the 16S-23S intergenic spacer (ITS) of Streptococcus iniae (Berridge et al. 1998) and Piscirickettsia salmonis (Marshall et al. 1998).

Yet another widely used approach has been to focus on the gene encoding the 16S small subunit of the bacterial ribosomal RNA (rRNA). All bacterial genomes contain at least 1 copy of the 16S rRNA gene. It is wellknown that the sequence of the 16S rRNA gene contains a number of regions that are highly conserved among all eubacterial species and are thought to be associated with common structural functions in the assembled ribosomal complex (Van de Peer et al. 1996). Conversely, there are regions of the nucleotide sequence of the 16S rRNA gene that are considerably more variable due to nucleotide insertions, deletions, and polymorphisms. Up to this point, published molecular assays for fish pathogens targeting the 16S rRNA gene have used primers designed to hybridize to highly variable regions. Thus, even though all eubacterial genomes contain at least 1 copy of this gene, the assays are species-specific. Examples include speciesspecific assays for Flavobacterium psychrophilum, Flavobacterium columnare, and Flexibacter maritimus (Bader \& Shotts 1998), Mycobacterium marinum (Knibb et al. 1993), Aeromonas salmonicida (Høie et al. 1997), Yersinia ruckeri (Gibello et al. 1999) and Renibacterium salmoninarum (Rhodes et al. 1998).

Here we report the application of a terminal restriction fragment length polymorphism (T-RFLP) assay, one step of which involves PCR primers that, unlike those cited above, target 2 highly conserved regions of the 16S gene. This method represents a modification of a technique reported previously for differentiation of species of Mycobacterium (Avaniss-Aghajani et al. 1996). T-RFLP has also been widely used to characterize complex microbial communities (Liu et al. 1997). In this work, presumptive identification of a bacterial fish pathogen is achieved by digestion of the resultant amplified DNA into genus/species-specific fragments using restriction endonucleases that target variable regions within the amplicon. This assay can identify bacterial pathogens to at least the genus level without any need to culture the organism(s). The utility of this method was demonstrated on genomic DNA from a variety of common fish pathogens as well as in salmonid kidney tissue spiked with a known number of bacterial cells of a given species. The method was further demonstrated by detecting and identifying bacterial pathogens in the kidney tissue of 2 naturally infected salmonids.

\section{MATERIALS AND METHODS}

Bacterial strains, culture and enumeration. Table 1 lists bacterial strains used in this work. All Aeromonas and Vibrio species were grown in trypticase soy (TS) broth or on TS agar, while both Flavobacterium species were cultured on tryptone yeast extract with salts (TYES) agar or in TYES broth media. All bacterial species were enumerated from log-phase cultures as colony-forming units (CFU) by standard plate counts on the appropriate agar.

Kidney tissue origin and preparation. Rainbow trout Oncorhynchus mykiss kidney tissue, which in subsequent analyses was found to be free of any detectable bacteria, was obtained from Nicholas Gudkovs, Australian Animal Health Laboratory, CSIRO, Geelong, Victoria, Australia. Kidney tissues from infected Atlantic salmon Salmo salar and sockeye salmon $O$. nerka were obtained from a local commercial aquaculture facility and the Manchester Research Station of the Northwest Fisheries Science Center, respectively. In all cases, tissues were combined with $1 \times$ PBS (70 $\mu \mathrm{l} / 25 \mathrm{mg}$ tissue) and homogenized using a sterile Kontes Tenbroeck Tissue Grinder (Fisher Scientific). Homogenized tissue was aliquoted $(70 \mu \mathrm{l})$ into $1.7 \mathrm{ml}$ microfuge tubes and frozen at $-20^{\circ} \mathrm{C}$ for future use. The PBS diluent was prepared using sterile, United States Pharmacopeia (USP)-grade water (Abbott Laboratories).

Extraction of genomic DNA from cultured bacteria. A variety of fish pathogens were studied in this work. With few exceptions (see below) genomic DNA was extracted from Gram-negative organisms using a single protocol. One $\mathrm{ml}$ of cells from overnight culture was pelleted at 6000 relative centrifugal force (rcf) for $15 \mathrm{~min}$ and washed by resuspension in $1.0 \mathrm{ml}$ of $50 \mathrm{mM}$ Tris-HCl, 50 mM EDTA, pH 8.0, followed by centrifugation at $6000 \mathrm{rcf}$ for $15 \mathrm{~min}$ and resuspension in $800 \mu \mathrm{l}$ of wash buffer. Upon addition of $100 \mu \mathrm{l}$ of $20 \mathrm{mg} \mathrm{ml}^{-1}$ lysozyme (Sigma), the cells were incubated for $10 \mathrm{~min}$ at room temperature. Following the addition of $10 \mu \mathrm{l}$ 
Table 1. Bacterial strains examined in this study

\begin{tabular}{|c|c|c|}
\hline Species & Strain designation & Source \\
\hline Aeromonas salmonicida & $\begin{array}{l}49385 \\
\text { NB8601 } \\
\text { NB8801 } \\
\text { NCMB } 1102 \\
\text { A450 }\end{array}$ & $\begin{array}{l}\text { ATCC } \\
\text { Debra Milton }^{\mathrm{a}} \\
\text { Debra Milton } \\
\text { Debra Milton } \\
\text { C. Michel }\end{array}$ \\
\hline $\begin{array}{l}\text { Aeromonas veronii bv. } \\
\quad \text { sobria }\end{array}$ & $\begin{array}{l}\text { BC88 } \\
\text { L3 } \\
\text { L4 }\end{array}$ & $\begin{array}{l}\text { Sylvia Kirov }{ }^{c} \\
\text { Human isolate } \\
\text { Human isolate }\end{array}$ \\
\hline Aeromonas hydrophila & $\begin{array}{l}\text { L1 } \\
\text { L2 } \\
\text { Ah65 } \\
\text { TF7 }\end{array}$ & $\begin{array}{l}\text { Human isolate } \\
\text { Human isolate } \\
\text { S. Peter Howard } \\
\text { William Kay }^{\mathrm{e}}\end{array}$ \\
\hline $\begin{array}{l}\text { Flavobacterium } \\
\text { psychrophilum }\end{array}$ & $\begin{array}{l}\text { BH1cb-8 } \\
\text { NCMB } 1947 \\
\text { CCC6-86 } \\
\text { CHChS19-85 }\end{array}$ & $\begin{array}{l}\text { Rich Holt }{ }^{\mathrm{f}} \\
\text { Rich Holt } \\
\text { Rich Holt } \\
\text { Rich Holt }\end{array}$ \\
\hline Flavobacterium columnare & $\begin{array}{l}\text { BRSg6-82 } \\
\text { Klsuk13-96 } \\
\text { WHChS8K-96 }\end{array}$ & $\begin{array}{l}\text { Rich Holt } \\
\text { Rich Holt } \\
\text { Rich Holt }\end{array}$ \\
\hline Vibrio anguillarum & $\begin{array}{l}775 \\
1297 \\
19264 \\
1733 \\
1173 \\
1347\end{array}$ & $\begin{array}{l}\text { Ron Paschog } \\
\text { Debra Milton } \\
\text { Debra Milton } \\
\text { Debra Milton } \\
\text { Debra Milton } \\
\text { Debra Milton }\end{array}$ \\
\hline Vibrio ordalii & $\begin{array}{l}\text { C74-48 } \\
45-5-k i d \\
33509\end{array}$ & $\begin{array}{l}\text { Russ Herwig }^{\mathrm{h}} \\
\text { Russ Herwig } \\
\text { ATCC }\end{array}$ \\
\hline $\begin{array}{l}\text { Renibacterium } \\
\text { salmoninarum }\end{array}$ & $\begin{array}{l}33209 \\
\text { Carson 5b } \\
\text { Marion Forks ChS-94 } \\
\text { Lake Billy Chinook } \\
\text { LR-95 R-19 ChS1999 } \\
\text { SS-ChS-94-1 } \\
\text { MK-91 ChS\#2 } \\
\text { Little Goose ChS-84 } 1998 \\
\text { Bonneville-5-CBS-98 } \\
\text { 91-127 Idaho } \\
\text { Round Butte ChSA } \\
\text { Cow-ChS-94 } \\
\text { Bonneville \#1 CHF } \\
\text { Willamette ChS \# } 17 \\
\text { Lost } 18\end{array}$ & $\begin{array}{l}\text { ATCC } \\
\text { Craig Banner } \\
\text { Craig Banner } \\
\text { Craig Banner } \\
\text { Craig Banner } \\
\text { Craig Banner } \\
\text { Craig Banner } \\
\text { Craig Banner } \\
\text { Craig Banner } \\
\text { Craig Banner } \\
\text { Craig Banner } \\
\text { Craig Banner } \\
\text { Craig Banner } \\
\text { Craig Banner } \\
\text { Frank Poysky }\end{array}$ \\
\hline \multicolumn{3}{|c|}{ 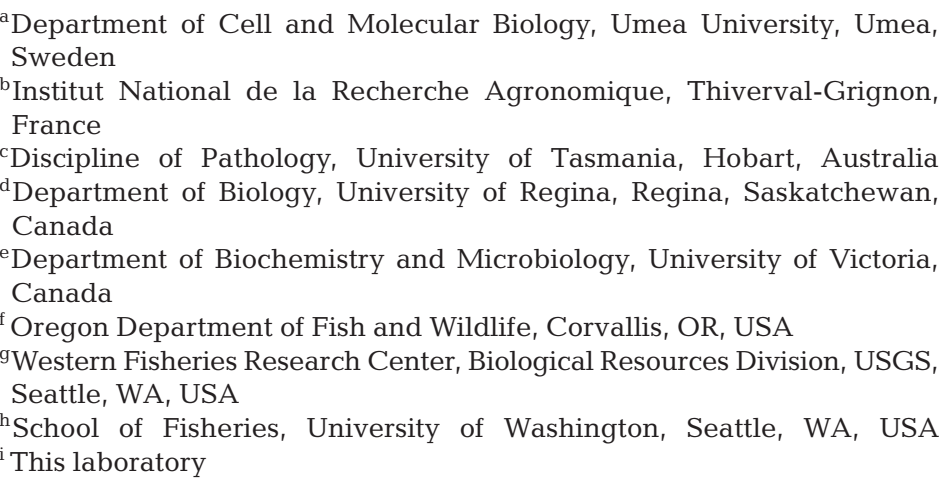 } \\
\hline
\end{tabular}

$20 \%$ lauryl sulfate (SDS) and $50 \mu \mathrm{l}$ of $10 \mu \mathrm{g} \mathrm{ml} \mathrm{m}^{-1}$ predigested Proteinase $\mathrm{K}$ (Sigma), cells were lysed by incubation at $37^{\circ} \mathrm{C}$ for $1 \mathrm{~h}$, mixing every $15 \mathrm{~min}$. The lysate was then extracted twice with an equal volume of phenol saturated with $50 \mathrm{mM}$ Tris- $\mathrm{HCl}, \mathrm{pH} 8.0$ (mixed by vortexing every $10 \mathrm{~min}$ and incubated at $37^{\circ} \mathrm{C}$ for $30 \mathrm{~min}$ total), followed by 1 extraction with an equal volume of phenol:chloroform (1:1) and 1 extraction with chloroform. The genomic DNA was precipitated by adding $1 / 10$ volume of $3 \mathrm{M}$ sodium acetate, pH 4.8 and 2.5 volumes absolute ethanol. The DNA was then spooled out, washed twice with $75 \%$ ethanol and once with absolute ethanol. After air-drying for ca. $10 \mathrm{~min}$, the purified genomic DNA was then resuspended in $1 \times$ TE $(10 \mathrm{mM}$ TrisEDTA, 1 mM EDTA, pH 8.0). Renibacterium salmoninarum genomic DNA was isolated using a protocol described elsewhere (Rhodes et al. 1998). For preparation of template for primers targeting plasmid DNA, a single colony of cells was picked and boiled in sterile water.

Isolation of total DNA from spiked kidney tissue. After estimation of cell densities of mid-log cultures based on optical density determinations, cells were pelleted by centrifugation at $6000 \mathrm{rcf}$ for $15 \mathrm{~min}$. The pellet was resuspended in $1 \times$ PBS (prepared with sterile, USP-grade water) and centrifuged as above. After discarding the supernatant, the pellet was then resuspended in $1 \mathrm{ml} 1 \times$ PBS. The washed cells were serially diluted with $1 \times$ PBS to give suspensions containing from ca. $1 \times 10^{3}$ to $1 \times 10^{8}$ cells ml ${ }^{-1}$. Addition of $10 \mu \mathrm{l}$ of each suspension to $70 \mu \mathrm{l}$ of homogenized kidney resulted in tissue spiked with from ca. $1 \times 10^{1}$ to $1 \times 10^{6}$ cells $25 \mathrm{mg}^{-1}$. Actual numbers of CFU added to homogenates were determined from plate counts of $100 \mu \mathrm{l}$ of selected serial dilutions on the appropriate media. Total DNA (bacterial and host) was then extracted from each spiked tissue sample using the QIAamp DNA Mini Kit according to the tissue protocol recommended by the manufacturer (Qiagen) for Gram-negative bacteria.

Due to the universal nature of the primers used in this assay and the need to maintain overall sterility, all extraction 
steps were performed in a laminar flow hood (The Baker Company). In addition, a number of assay controls were prepared routinely to ensure the integrity of reagents and to simplify troubleshooting in the event of false positives due to inadvertent contamination. Along with the usual PCR-negative control to check for contamination of PCR reagents, a number of other controls were run. To check for bacterial DNA in rainbow trout kidney, $10 \mu \mathrm{l}$ of cell diluent $(1 \times$ PBS $)$ was added to $70 \mu \mathrm{l}$ of kidney tissue homogenate and run through the extraction protocol in parallel with spiked tissue (kidney tissue control). Similarly, kit reagents were monitored by running $80 \mu \mathrm{l}$ of $1 \times$ PBS through the procedure in parallel (reagent control). Finally, the purity of the diluent was routinely checked by performing PCR on the appropriate volume of $1 \times$ PBS in parallel with the extraction products (PBS control).

Synthetic oligonucleotide primers. The gene encoding the $16 \mathrm{~S}$ subunit of the bacterial ribosome was amplified using a previously described pair of universal primers (Avaniss-Aghajani et al. 1996). The sense primer (ULF500), 5'-GCCTAACACATGCAAGTCGA-3', corresponds to nucleotides 46 to 65 of the Escherichia coli 16S rRNA gene while the antisense primer (ULR500), 5'-CGTATTACCGCGGCTGCTGG-3', corresponds to nucleotides 518 to 537 of the same gene. Both primers were labeled at the $5^{\prime}$ end with fluorescent phosphoramidite dyes: HEX for ULF500, which fluoresces blue, and 6-FAM for ULR500, which fluoresces yellow. Labeled primers were synthesized by PerkinElmer Applied Biosystems.

PCR amplification. PCR reactions were prepared in a PCR Workstation (AirClean Systems) located in a laboratory where no microbiological work is performed. A single set of conditions was used to amplify template DNA with the fluorescently labeled primers. Each $75 \mu \mathrm{l}$ reaction contained $2.5 \mathrm{mM} \mathrm{MgCl} 2,100 \mathrm{nM}$ each dNTP, $100 \mathrm{nM}$ each primer and $1 \mathrm{U}$ of Taq polymerase (Qiagen). Only sterile, USP-grade water (Abbott Laboratories) was used in all PCR reactions and for preparation of primer working stocks. Each reaction received $75 \mathrm{ng}$ of genomic DNA or $15 \mu \mathrm{l}$ of DNA extracted from kidney seeded with known numbers of bacterial CFU. For amplification of templates extracted from kidney tissue, the reactions were supplemented with bovine serum albumin (Roche Diagnostics) to a final concentration of $0.6 \mathrm{ng} \mathrm{ll}^{-1}$ to prevent PCR inhibition by melanin granules present in kidney tissue (Eckhart et al. 2000). PCR amplification was performed using a Progene thermocycler (Techne) equipped with a heated lid. The initial cycle consisted of $3 \mathrm{~min}$ at $94^{\circ} \mathrm{C}, 30 \mathrm{~s}$ at $57^{\circ} \mathrm{C}$ and $30 \mathrm{~s}$ at $72^{\circ} \mathrm{C}$, followed by 35 cycles at 94,57 and $72^{\circ} \mathrm{C}$, all $30 \mathrm{~s}$, a final cycle at 94 and $57^{\circ} \mathrm{C}$, both $30 \mathrm{~s}$, and a final extension of $10 \mathrm{~min}$ at $72^{\circ} \mathrm{C}$. PCR amplicons were resolved by agarose gel electrophoresis in
$2 \%$ agarose in $40 \mathrm{mM}$ Tris-acetate, $1 \mathrm{mM}$ EDTA, and stained with $1 \mathrm{mg} \mathrm{ml}^{-1}$ ethidium bromide.

Restriction digestion. Prior to digestion of PCR amplicons, all products were purified to remove residual primers, salts, and other reactants using the Ultraclean PCR Clean-up Kit (Mo Bio Laboratories). Purified products were then digested with the following restriction endonucleases (New England Biolabs), all with 4-base recognition sites: DpnII, HaeIII, HhaI, RsaI, MspI, and AluI. Digestions were carried out according to the manufacturer's protocol. Prior to fragment analysis, each digest was purified using the QIAquick Nucleotide Removal Kit (Qiagen) to desalt the product and remove proteins.

Fragment analysis. An ABI PRISM 310 Genetic Analyzer (Applied Biosystems) with laser-induced fluorescence (LIF) detection and GeneScan Analysis software (version 2.0.2) was used to size the terminal restriction fragments. The software sizes the terminal fragments by comparing their migration times to those of a set of internal size standards (GS-500 TAMRA, Applied Biosystems) that are distinguished from the restriction fragments by their red fluorescence. The TAMRA was prepared by addition of $15 \mu$ l of stock to $667 \mu$ of formamide. The TAMRA standard $(10 \mu \mathrm{l})$ was then combined with $2 \mu$ l of desalted digest in a 96-well plate. Samples were heat denatured for $6 \mathrm{~min}$ at $96^{\circ} \mathrm{C}$ prior to analyses.

Sequencing. In a few cases it was necessary to verify the results of the fragment analyses and the identity of PCR products by direct sequencing of the PCR amplicon. Both strands were sequenced in all cases. Sequencing reactions were prepared using the Big Dye Terminator Cycle Sequencing Ready Reaction Kit (Applied Biosystems) according to the manufacturer's protocol. Sequencing was performed on an ABI PRISM 377 DNA Sequencer by Albany Molecular Research. Sequence data from both strands were aligned and reconciled using Sequencer 3.0 (Gene Codes Corp). Species identification was confirmed by comparing the DNA sequence to the GenBank database using BLASTn (basic local alignment search tool, standard nucleotide comparison; Altschul et al. 1990) on-line, available at http://www.ncbi.nlm.nih.gov/BLAST/.

\section{RESULTS}

\section{Terminal RFLP analysis}

In this work, both the conserved and variable regions of the 16S rRNA gene were exploited for the detection and identification of bacterial pathogens. Fig. 1 provides a schematic summary of the main steps of the protocol. The universal primer pair ULF500 and ULR- 


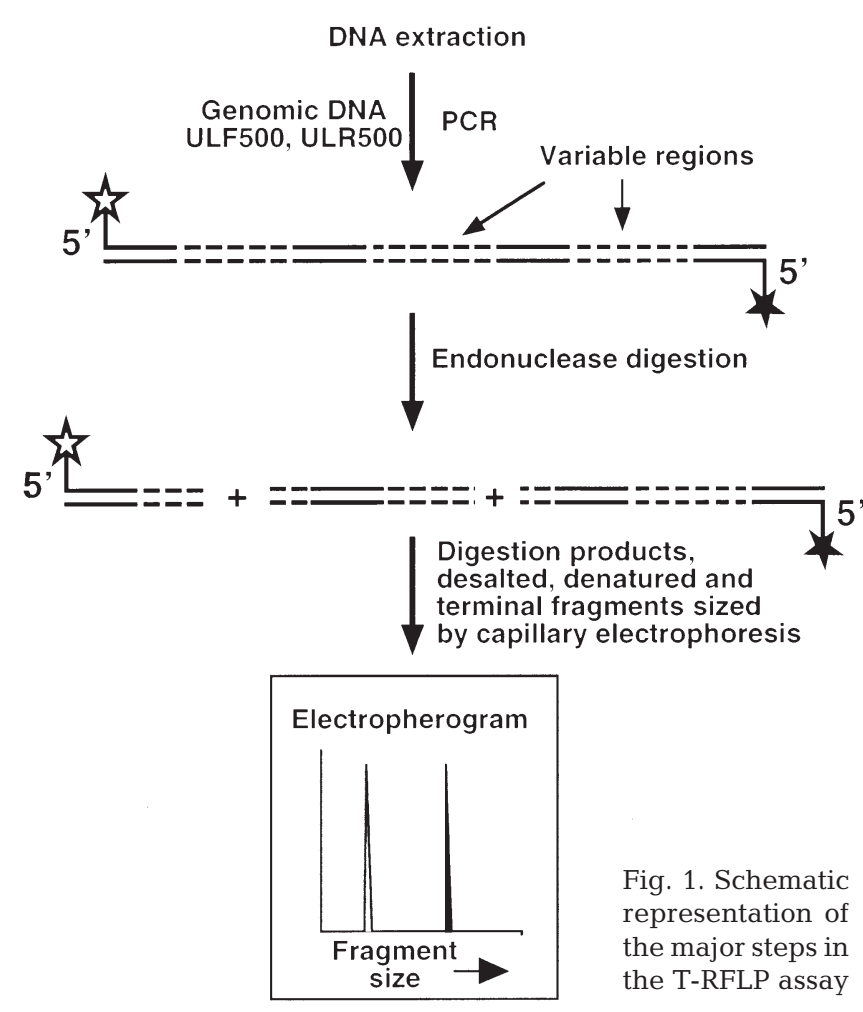

500, each bearing a different fluorescent dye label, targeted 2 universally conserved regions of the eubacterial 16S gene and therefore amplify DNA from virtually all bacterial species giving a product of essentially the same size (ca. $500 \mathrm{bp}$ ). These primers flank 3 variable regions of the 16S rRNA gene (depicted as dashed regions in Fig. 1) that were exploited for species identification in subsequent fragment analyses. Since ULF500 and URL500 were each labeled on the 5' end with 2 distinguishable fluorescent dyes, the resultant PCR amplicon was uniquely labeled on the 5' end of each strand. The initial amplification step was followed by digestion of the labeled amplicon by a series of restriction endonucleases all with 4 base recognition sites. If the PCR amplicon contained one or more restriction enzyme recognition sites for a given endonuclease, two or more fragments resulted. The 2 terminal fragments each bore a unique fluorescent dye. These 2 fragments were then detected by their blue or yellow fluorescence and sized by capillary electrophoresis with LIF detection. Due to the presence of hypervariable regions, the series of 6 digestions was expected to lead to a characteristic set of 12 labeled terminal restriction fragments. A match of all 12 fragment sizes with an entry in the Fish Bacterial Pathogen T-RFLP database (described below) provided preliminary identification of the bacterial agent to at least the genus, but more typically the species level.

\section{Construction of a searchable T-RFLP library for bacterial fish pathogens}

We have compiled a searchable library that will enable the user to infer the presumptive identity of a number of common fish pathogens based on the predicted terminal fragment lengths for all 6 restriction endonuclease digestions. To construct the library for a given bacterial pathogen, GenBank was searched for submissions of $16 \mathrm{~S}$ gene sequences that include the ULF500/ULR500 primer pair target sites. The sequence of the predicted amplified fragment was then searched for recognition sequences for DpnII, HaeIII, HhaI, RsaI, MspI and AluI using DNASIS software (Hitachi Software Engineering). Based upon this search, the expected sizes of both the blue and yellow fragments were compiled for each enzyme and entered into an Excel spreadsheet. This procedure was repeated for all entries for a large number of bacterial pathogens of fish. To search the library, the user simply enters a set of 12 observed terminal fragment sizes. If a given entry matches the corresponding library entry ( \pm 10 bases), it is given a score of ' 1 '. Thus for a full set of 6 digests, a total score of 12 provides presumptive identification of the bacterial pathogen. This library and instructions for its use are available at http://www.nwfsc.noaa.gov/reutd/molmicro/ t-rflp/.

\section{T-RFLP analysis of genomic DNA}

The fluorescently labeled primers ULF500 and ULR500 were used as described above to amplify a portion of the $16 \mathrm{~S}$ gene of all strains of bacterial species listed in Table 1. In all cases, the amplified portion of the 16S rRNA gene was of the predicted size (ca. $500 \mathrm{bp}$, data not shown). A series of 6 restriction endonucleases with 4 base recognition sites was used to digest PCR products from genomic DNA of the indicated species and strains. Table 2 displays predicted and observed sizes of the terminal restriction fragments from digests of labeled amplicons from all strains used in this work. Except where noted, the observed terminal fragment sizes for strains of a given species were found to agree within $1 \mathrm{bp}$. For each set of strains of a species, the predicted fragment sizes are given. These predictions are based on a consensus of a survey of GenBank entries for each given bacterial species. The accession numbers of the entries used to arrive at the predicted fragment sizes are also given as a series of footnotes. With few exceptions (discussed below), the fragment sizes were found to be close to the consensus prediction of the GenBank survey. 
Table 2. Observed terminal restriction fragment sizes for selected fish bacterial pathogens. Each digest results in a blue (B) and yellow (Y) fragment. The predicted size of each fragment is given for 6 digests of each species and is based on the consensus of a number of entries in GenBank. The accession numbers of GenBank submissions used to arrive at predicted fragment sizes are given in the footnotes. Except where noted, observed fragment sizes for all strains of a given species agree within 1 base, e.g. fragment sizes for all 15 strains of Renibacterium salmoninarum were nearly identical

\begin{tabular}{|c|c|c|c|c|c|c|c|c|c|c|c|c|}
\hline \multirow[t]{2}{*}{ Strain } & \multicolumn{2}{|c|}{ DpnII } & \multicolumn{2}{|c|}{ HaeIII } & \multicolumn{2}{|c|}{ HhaI } & \multicolumn{2}{|c|}{ RsaI } & \multicolumn{2}{|c|}{ MspI } & \multicolumn{2}{|c|}{ AluI } \\
\hline & B & $\mathrm{Y}$ & B & $\mathrm{Y}$ & $\mathrm{B}$ & $\mathrm{Y}$ & B & $\mathrm{Y}$ & B & $\mathrm{Y}$ & $\mathrm{B}$ & $\mathrm{Y}$ \\
\hline \multicolumn{13}{|c|}{ Aeromonas salmonicida } \\
\hline Observed (5/5) & 82 & 227 & 168 & 116 & 415 & 75 & 490 & 489 & 48 & 28 & 34 & 245 \\
\hline Predicted $^{\mathrm{a}}$ & 85 & 229 & 170 & 120 & 419 & 78 & 494 & 494 & 52 & 32 & 38 & 248 \\
\hline \multicolumn{13}{|c|}{ A. veronii bv. sobria } \\
\hline Observed (3/3) & 82 & 227 & 168 & 115 & 175 & 317 & 489 & 488 & 48 & 28 & 33 & 58 \\
\hline Predicted $^{\mathrm{b}}$ & 85 & 229 & 170 & 120 & 177 & 319 & 494 & 494 & 52 & 32 & 38 & 62 \\
\hline \multicolumn{13}{|l|}{ A. hydrophila } \\
\hline Observed (3/4) & 234 & 227 & 168 & 116 & 175 & 317 & 489 & 489 & 48 & 28 & 33 & 246 \\
\hline $\mathrm{Ah} 65^{\mathrm{C}}$ & 81 & 227 & 168 & 115 & 414 & 75 & 489 & 488 & 48 & 29 & 34 & 246 \\
\hline Predicted $^{\mathrm{d}}$ & 237 & 229 & 170 & 120 & 177 & 319 & 494 & 494 & 52 & 32 & 38 & 248 \\
\hline \multicolumn{13}{|c|}{ Flavobacterium psychrophilum } \\
\hline Observed $(4 / 4)$ & 248 & 28 & 472 & 476 & 47 & 152 & 263 & 48 & 42 & 427 & 191 & 57 \\
\hline Predicted $^{\mathrm{e}}$ & 251 & 33 & 479 & 479 & 50 & 154 & 267 & 51 & 45 & 431 & 194 & 60 \\
\hline \multicolumn{13}{|l|}{ F. columnare } \\
\hline Observed (3/3) & 252 & 28 & 139 & 338 & 51 & 152 & 84 & 49 & 45 & 427 & 30 & 57 \\
\hline Predicted $^{\mathrm{f}}$ & 254 & 33 & 143 & 339 & 54 & 154 & 88 & 51 & 49 & 431 & 33 & 60 \\
\hline \multicolumn{13}{|l|}{ Vibrio anguillarum } \\
\hline $775,19264,1173$ & 233 & 227 & 145 & 115 & 335 & 157 & 386 & 100 & 452 & 29 & 201 & 245 \\
\hline Predicted ${ }^{g}$ & 237 & 229 & 147 & 323 & 335 & 158 & 388 & 103 & 457 & 32 & 202 & 247 \\
\hline 1347,1297 & 233 & 227 & 145 & 115 & 335 & 65 & 386 & 99 & 453 & 28 & 201 & 245 \\
\hline Predicted ${ }^{\mathrm{h}}$ & 237 & 229 & 147 & 323 & 335 & 67 & 388 & 103 & 457 & 32 & 202 & 247 \\
\hline $1733^{\mathrm{i}}$ & 233 & 227 & 145 & 115 & 335 & 157,65 & 386 & 100 & 452 & 29 & 201 & 245 \\
\hline \multicolumn{13}{|l|}{ V. ordalii } \\
\hline Observed (3/3) & 232 & 227 & 144 & 115 & 335 & 157 & 384 & 99 & 452 & 29 & 201 & 245 \\
\hline Predicted $^{\mathrm{j}}$ & 235 & 229 & 147 & 120 & 335 & 159 & 389 & 103 & 458 & 32 & 202 & 248 \\
\hline \multicolumn{13}{|c|}{ Renibacterium salmoninarum } \\
\hline Observed (15/15) & 479 & 477 & 192 & 107 & 33 & 439 & 429 & 47 & 242 & 25 & 199 & 260 \\
\hline Predicted $^{\mathrm{k}}$ & 481 & 481 & 191 & 112 & 40 & 443 & 430 & 51 & 242 & 32 & 199 & 263 \\
\hline \multicolumn{13}{|c|}{ 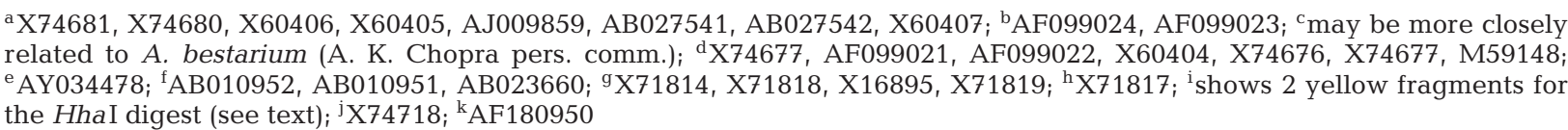 } \\
\hline
\end{tabular}

\section{Detection and identification of bacteria in spiked kidney tissue}

Homogenized kidney tissue was spiked with serial dilutions of Flavobacterium psychrophilum cells ranging from $1.1 \times 10^{1}$ to $1.1 \times 10^{6}$ cells as determined by subsequent plate counts on TYES agar. Total DNA was extracted from each sample and the PCR amplification performed with fluorescently labeled primers. In Fig. $2 \mathrm{a}, 10 \mu \mathrm{l}$ of the PCR product from each of the spiked tissue samples with decreasing cell titers from lanes 3 through 13 was electrophoresed through a $2 \%$ agarose gel and stained with ethidium bromide. The characteristic bacterial 16S gene amplicon of about $500 \mathrm{bp}$ was visible to at least $730 \mathrm{CFU} 25 \mathrm{mg}^{-1}$ of tissue

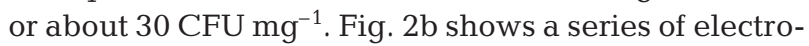
pherograms from the 310 analyses of the DpnII digests of selected samples from the same titration with terminal fragment lengths, 248 (blue) and 29 (yellow), that were close to those predicted for this species (Table 2). Inspection of the full series of electropherograms sup-

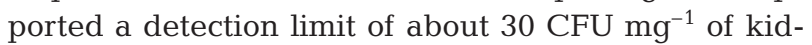
ney tissue (full data set not shown). A very similar detection limit was also found for titrations of Vibrio anguillarum, Aeromonas salmonicida, and A. hydrophila (data not shown).

\section{Identification of bacterial pathogens in naturally infected kidney tissue}

This assay was tested on kidney tissue from 2 sets of salmonid species believed to be suffering from bacterial infection. In the first example, kidney aseptically 

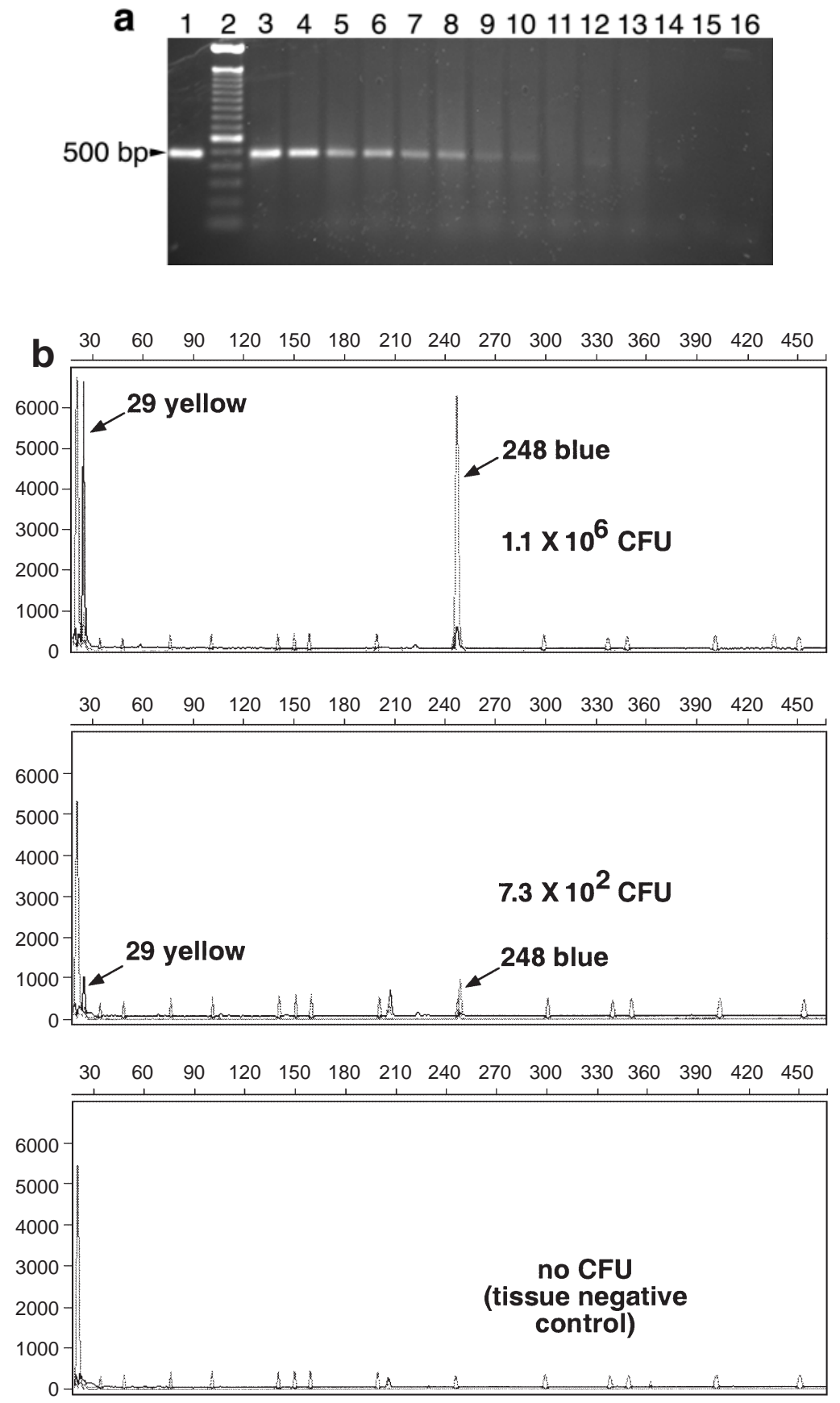

Fig. 2. Sensitivity of the T-RFLP assay for detection of Flavobacterium psychrophilum (strain BH1cb-81) in rainbow trout kidney. (a) Cells from a log phase broth culture were serially diluted and spiked into homogenized kidney tissue. Lane assignments: 1, PCR positive control, F. psychrophilum genomic DNA; 2,100 bp ladder; $3,1.1 \times 10^{6} \mathrm{CFU} ; 4,1.1 \times 10^{5} \mathrm{CFU} ; 5,1.1 \times 10^{4}$ $\mathrm{CFU} ; 6,7.3 \times 10^{3} \mathrm{CFU} ; 7,3.7 \times 10^{3} \mathrm{CFU}_{;} 8,1.1 \times 10^{3} \mathrm{CFU} ; 9,7.3 \times 10^{2} \mathrm{CFU}$; $10,3.7 \times 10^{2} \mathrm{CFU}_{;} 11,1.1 \times 10^{2} \mathrm{CFU} ; 12,1.1 \times 10^{1} \mathrm{CFU}_{;} 13$, kidney tissue negative control; 14 , reagent negative control; 15 , PBS negative control; 16 , PCR negative control. (b) Electropherograms for the DpnII digestions of PCR products from kidney sample spiked with $1.1 \times 10^{6}, 7.3 \times 10^{2}$ and 0 CFUs of F. psychrophilum (see Fig. 3a). Along with the size standards (peaks that have peaks heights generally less than 500 units), both upper electropherograms display a blue fragment of 248 bases and a yellow fragment of 29 bases, sizes close to those predicted for F. psychrophilum and shown in Table 2 collected from 2 Atlantic salmon Salmo salar suspected of having furunculosis was extracted and amplified using this protocol. In both cases, a band of the expected size was observed (data not shown). Amplified DNA from both fish was digested and analyzed as described in 'Materials and methods'. In both cases, the full set of fragment sizes matched those expected for Aeromonas salmonicida given in Table 2. In the second example, kidney from sockeye salmon Oncorhynchus nerka, with evidence of heavy Renibacterium salmoninarum infection according to the indirect fluorescent antibody test (Bullock \& Stuckey 1975), was extracted. DNA amplified with the labeled universal primers and resolved on a gel again showed the presence of a single band of ca. 500 bp (data not shown). As expected, T-RFLP analysis of the ca. $500 \mathrm{bp}$ amplicon gave a set of fragments (Table 2 ) exactly matching the prediction for $R$. salmoninarum. The extraction protocol used in this work has been optimized for Gram-negative organisms; therefore, the detection limit for the Gram-positive $R$. salmoninarum is likely not as low as that found for Gramnegative bacteria. Nonetheless, this result shows that the protocol can also be expected to detect $R$. salmoninarum and other Gram-positive species in the kidney tissue of heavily infected fish.

\section{Differentiation of Vibrio anguillarum from $V$. ordalii}

A comparison of the observed sizes of the terminal fragments for Vibrio ordalii (all strains) with those of $V$. anguillarum (strains 775, 19264, and 1173) indicates that this assay is incapable of differentiating these 2 closely related species. However, species differentiation can be accomplished by subsequent testing using species-specific primers. Fig. 3a shows the products from PCR using primers targeting the hemolysin gene, vah1, of $V$. anguillarum (Hirono et al. 1996). All 6 strains of this species produced the expected 494 bp product (lanes 1 to 6), while none of the $V$. ordalii strains yielded fragments (lanes 8 to 10 ). 


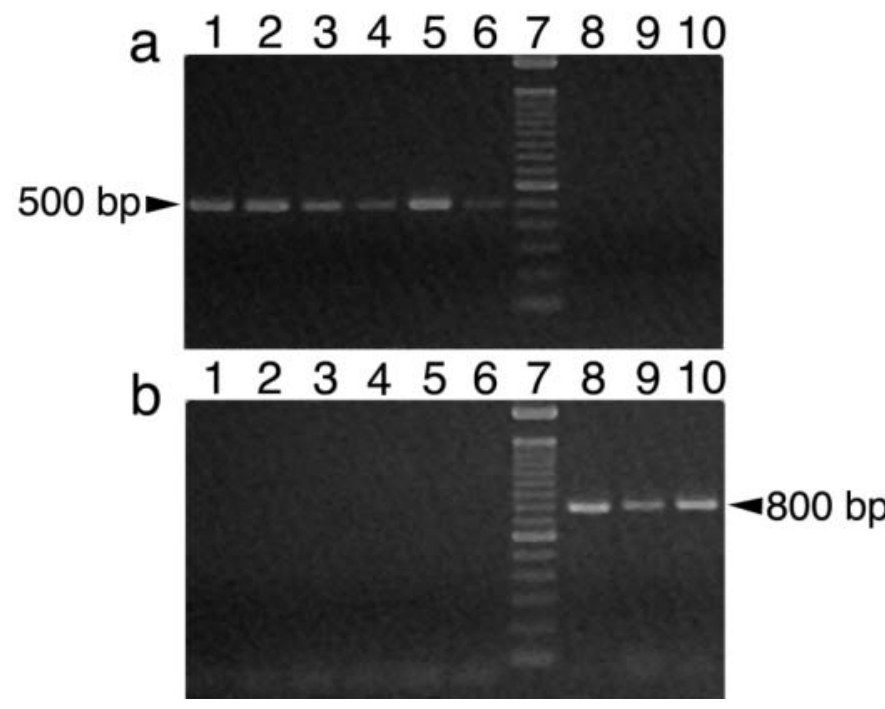

Fig. 3. Differentiation of Vibrio anguillarum from $V$. ordalii using primers targeting (a) the vah1 gene of $V$. anguillarum (Hirono et al. 1996), and (b) the repM gene carried by the plasmid pMJ101 present in all known isolates of $V$. ordalii (Bidenost et al. 1999). Both sets of products were resolved on $2 \%$ agarose and stained with ethidium bromide. In both gels, lanes 1 to 6 are $V$. anguillarum strains and 8 to 10 are $V$. ordalii strains. Lanes: 1,$775 ; 2,1347 ; 3,19264 ; 4,1173 ; 5,1247 ; 6$, $1733 ; 7,100$ base pair ladder; 8,$33509 ; 9,45-5$-kid; 10, C74-48

Conversely, Fig. 3b illustrates the usefulness of primers targeting the plasmid pMJ101 carried by $V$. ordalii (Bidinost et al. 1999), where all $3 \mathrm{~V}$. ordalii strains produced the expected $788 \mathrm{bp}$ product (lanes 8 to 10 ) that was absent in all $6 \mathrm{~V}$. anguillarum strains (lanes 1 to 6 ). Both of these amplicons were sequenced and showed nearly complete identity with relevant portions of GenBank sequences for vah1 and pMJ101 (accession nos. S83534 and U68169, respectively).

\section{DISCUSSION}

The method described above was adapted from a protocol originally reported by Avaniss-Aghajani et al. $(1994,1996)$ as a means of differentiating species of Mycobacteria; however, these workers labeled only the forward primer. Our use of different fluorescent labels for both the forward and reverse primers doubles the information provided and in doing so potentially increases the power of the assay for species identification.

Conventional protocols for diagnosing bacterial pathogens in fish pathology laboratories involve attempts to culture the putative pathogen on standard media for subsequent biochemical or serological analyses. The time required for growth can range from a day to sev- eral weeks. Furthermore, it is possible that the pathogenic organism is not culturable, making conventional approaches towards identification impossible. An important advantage of the universal approach described here is the potential for identification of a bacterial pathogen directly from kidney tissue without the need for time-consuming bacterial culturing.

With the now widespread availability of sequencing technology, an attractive alternative to the T-RFLP strategy for identification of a bacterial pathogen is amplification of the 16S gene using unlabeled universal primers followed by direct sequencing of the amplicon and a subsequent BLAST search. We have used this approach in our laboratory for identification of bacteria in pure culture with some success. However, unlike the direct sequencing strategy, the T-RFLP approach described here will also allow the simultaneous detection and identification of multiple species. The presence of 2 different species of bacteria would be expected to give 2 different sets of terminal fragments, typically of differing sizes. The only challenge in this case would be determination of which blueyellow fragment pairing arises from digestion of a given bacterial amplicon. Although their occurrence might initially seem unusual, in practice instances of multiple infections may be relatively common in some salmonids. This is due to the ubiquity of Renibacterium salmoninarum among certain populations (Elliott et al. 1997). It may be relatively common that salmonids suffering from acute infections may also be chronically infected with $R$. salmoninarum. Given the demonstration above that it is possible to detect $R$. salmoninarum using this assay, it is likely that detection of the presence of multiple bacterial infections will not be rare in practice. An additional advantage of the T-RFLP approach over that of direct sequencing is suggested by electropherograms from kidney samples spiked with a titration of Flavobacterium psychrophilum cells, a partial set of which is shown in Fig. 2b. An examination of the full set shows that the height of the fragment peaks decreases with the number of cells added to the tissue. This observation suggests that the assay might offer semi-quantitative information on the extent of the bacterial infection at least for Gram-negative organisms. This assertion is somewhat speculative, however, and would require further confirmation with a variety of bacterial species.

It is important to state that the universality of this primer pair requires precautions beyond those usually taken with PCR to avoid the occurrence of false positives due to exogenous bacterial DNA. Of central importance is the use of very high quality water for preparation of all reagents used in DNA extraction as well as PCR amplification. In preliminary work, HPLCgrade water from all lots tested was found to give false 
positives due to contaminating bacterial DNA. Sterile USP-grade water manufactured for human infusion has proven to be much more reliable. We have also mentioned the use of laminar flow hoods for both DNA extraction from tissues as well as preparation of PCR reactions, the latter preferably segregated from areas where no microbiological work is being done. Moreover, it is prudent to UV-treat all plastics to destroy any residual bacterial DNA. Pipettors were cleaned and UV-treated routinely, and aerosol-resistant tips were always used. In addition, a separate set of pipettors was reserved exclusively for preparation of PCR reactions. It is also recommended that both sample preparation and PCR reagents be aliquoted to avoid having to open them more than once. It is our experience that problems of false positives with negative controls are essentially eliminated when all of the above practices are routinely applied.

Successful application of this method also requires a comprehensive database containing the predicted sizes of terminal fragments from all 6 enzyme digests for a wide range of bacterial pathogens. The most readily available source of bacterial 16S rRNA gene sequences is available through GenBank. An extensive survey of submitted sequences for several fish pathogens for which there are multiple submissions revealed that in many cases, multiple sequences reported for the same species predict fragment sizes that can be quite different. It is difficult to know whether such divergent predictions are due to actual sequence heterogeneity or to sequencing errors. It is of some comfort to note that in most cases, the predictions given in Table 2 are based upon the consensus of a large portion of the total submissions for a given species. However, this is not always the case. Notably, a survey of the submissions for Vibrio anguillarum yielded some 2 dozen submissions. Only about half of these entries contain a target site for the reverse primer ULR500 and thus are not predicted to produce an amplified product with the universal primer set. We have yet to find a bacterial species that will not produce the expected amplicon of ca. $500 \mathrm{bp}$. Therefore, these submissions appear to be questionable. Of those entries that are predicted to produce a $500 \mathrm{bp}$ amplicon, all predict a yellow terminal fragment produced from a HaeIII digest of 323 bases. Curiously, all 6 strains we tested for this work show a 115 base yellow fragment from this digest. Most of the 16S rRNA gene for one of the strains in Table 2, V. anguillarum 775, has previously been determined by Wiik et al. (1995) and deposited in GenBank (accession no. X71814). We also sequenced the relevant portion of the 16S rRNA gene from our isolate of $V$. anguillarum 775. Alignment of the 2 sequences reveals $100 \%$ identity except our sequence contains a $\mathrm{C}$ insertion at base 374 that leads to a HaeIII site $\left(\mathrm{GG}^{*} \mathrm{CC}\right)$ and predicts a 119 base yellow fragment, close to that observed (115). According to Wiik et al. (1995), their sequencing was performed manually whereas our sequence was obtained using an automated sequencer. Manual sequencing is known to be prone to errors due to GC base compression that perhaps would explain this discrepancy.

It is interesting to note that our analysis of the HhaI digests of the 6 Vibrio anguillarum strains finds that with a single exception, they fall into 2 groups. One contains 3 strains that show a 335 base blue fragment and a 157 base yellow fragment, close to the prediction of the majority of GenBank entries (Table 2). For 2 other strains we observed the 335 base blue fragment but a 65 base yellow fragment, close to the prediction of a single entry in GenBank (accession no. 71817). Interstrain heterogeneity in the $16 \mathrm{~S}$ gene sequence has been reported for several species, e.g. Xylella fastidiosa (Chen et al. 2000) and Streptococcus anginosus (Jacobs et al. 2000). In the remaining $V$. anguillarum strain (strain 1733) we find a blue fragment of the predicted size (335), but the electropherogram clearly shows 2 yellow fragments containing 157 and 65 bases of approximately equal area. This finding has been repeated taking care to ensure that only a single colony was picked for DNA extraction. It appears likely that this strain of $V$. anguillarum contains at least 2 copies of the 16S rRNA gene that differ in sequence. Most bacteria have multiple rRNA operons usually containing a copy of the 16S rRNA gene (Mylvaganam \& Dennis 1992). It is commonly assumed that interoperon copies of the 16S rRNA gene have essentially identical sequence. There are now several citations in the literature suggesting that this is not always the case. Interoperon sequence heterogeneity has been reported for Escherichia coli (Cilia et al. 1996), Phormium yellow leaf phytoplasma (Liefting et al. 1996), Мycobacterium celatum (Reischl et al. 1998), and Thermomonospora chromogena (Yap et al. 1999).

While the 16S gene for the majority of bacterial species is quite homogeneous among strains, it is clear that there is some heterogeneity in this gene for some species, such as Vibrio anguillarum (Table 2). Following the description of a RFLP assay for distinguishing Aeromonas species (Borrell et al. 1997), Graf (1999) studied the RFLP patterns of the 16S gene from 62 Aeromonas reference strains. It was reported that for most species studied, the restriction patterns varied little. However, 4 sets of differing restriction patterns were seen among 9 different strains of $A$. veronii biovar sobria. The author concluded by stating that molecular approaches such as the one described here require a broad database to be reliable for species identification. Subsequently, Graf's conclusions were questioned (Figueras et al. 2000) when it was suggested 
that the findings were due to misidentification of several of the strains as $A$. veronii biovar sobria. It would seem that the presence of interstrain variation among Aeromonas remains somewhat controversial. Nonetheless, an analysis of GenBank entries appears to support the assertion that interspecies variation of the $16 \mathrm{~S}$ gene is not unusual (Clayton et al. 1995). Our analysis and tabulation of multiple GenBank submissions for the 16S rRNA gene for a number of species of bacterial pathogens of fish should prove useful in application of this assay taking into account the probability of interspecies sequence variation.

We believe this assay to be a powerful tool for pathogen detection and identification. However, it is apparent from data presented here that it is not always capable of providing a definitive species identification. For example, due to the high degree of similarity of the 16S genes of Vibrio anguillarum and V. ordalii, application of species-specific PCR assays using primer pairs designed by Hirono et al. (1996) and Bidinost et al. (1999) was necessary to definitively distinguish between these 2 closely related organisms. Similarly, Aeromonas hydrophila Ah65 would be identified as A. salmonicida solely on the basis of analysis using this assay (Table 2). However, it has been suggested that this strain is more closely related to $A$. bestiarum (A. K. Chopra pers. comm.). Inspection of the 2 GenBank entries for A. bestiarum (accession nos. AB034759 and $\mathrm{X} 60406$ ) indicates that this portion of the $16 \mathrm{~S}$ gene is nearly identical to entries for $A$. hydrophila. Therefore, this assay alone would be unable to distinguish between these 2 species as well. Given these observations, it is advisable that presumptive species identification using this assay be confirmed by subsequent testing by PCR using species-specific primers wherever possible. Nonetheless, this assay provides a relatively rapid method for bacterial pathogen detection and identification at least to the genus level without a need to first culture the organism and without any preconceived notion of its identity.

Acknowledgements. We are grateful to Nicholas Gudkovs of the Australian Animal Health Laboratory, CSIRO, Geelong, VIC, Australia, for rainbow trout kidney tissue. Cindra Rathbone performed FAT analyses of Renibacterium salmoninarum-infected kidney tissue. We are especially grateful to Eric LaHood for technical advice, and Jeff Engebretson for design of the searchable T-RFLP library. We also wish to thank Linda Rhodes and Cyndy Pepe for a critical reading of the manuscript.

\section{LITERATURE CITED}

Altschul SF, Gish W, Miller W, Myers EW, Lipman DJ (1990) Basic local alignment search tool. J Mol Biol 215:403-410 Avaniss-Aghajani E, Jones K, Chapman C, Brunk C (1994) A molecular technique for identification of bacteria using small subunit ribosomal RNA sequences. Biotechniques 17:144-149

Avaniss-Aghajani E, Jones K, Holtzman A, Aronson T, Glover N, Boian M, Froman S, Brunk CF (1996) Molecular technique for rapid identification of mycobacteria. J Clin Microbiol 34:98-102

Bader JA, Shotts EB Jr (1998) Identification of Flavobacterium and Flexibacter species by species-specific polymerase chain reaction primers to the $16 \mathrm{~S}$ ribosomal RNA gene. J Aquat Anim Health 10:311-319

Baloda SB, Krovacek K, Eriksson L, Linné T, Månsson I (1995) Detection of aerolysin gene in Aeromonas strains isolated from drinking water, fish and foods by the polymerase chain reaction. Comp Immun Microbiol Infect Dis 18:17-26

Berridge BR, Fuller JD, de Azavedo J, Low DE, Bercovier H, Frelier PF (1998) Development of specific nested oligonucleotide PCR primers for the Streptococcus iniae 16S23S ribosomal DNA intergenic spacer. J Clin Microbiol 36: $2778-2781$

Bidinost C, Wilderman PJ, Dorsey CW, Acits LA (1999) Analysis of the replication elements of the pMJ101 plasmid from the fish pathogen Vibrio ordalii. Plasmid 42:20-30

Borrell N, Acinas SG, Figueras MJ, Martínez-Murcia AJ (1997) Identification of Aeromonas clinical isolates by restriction fragment length polymorphism of PCR-amplified rRNA genes. J Clin Microbiol 35:1671-1674

Bullock GL, Stuckey HM (1975) Fluorescent antibody identification and detection of the Corynebacterium causing kidney disease of salmonids. J Fish Res Board Can 32: $2224-2227$

Cascón A, Anguita J, Hernanz C, Sánchez M, Fernández M, Naharro G (1996) Identification of Aeromonas hydrophila hybridization group 1 by PCR assays. Appl Environ Microbiol 62:1167-1170

Chase DM, Pascho RJ (1998) Development of a nested polymerase chain reaction for amplification of a sequence of the p57 gene of Renibacterium salmoninarum that provides a highly sensitive method for detection of the bacterium in salmonid kidney. Dis Aquat Org 34:223-229

Chen T, Jarret RL, Qin X, Hartung JS, Banks D, Chang CJ, Hopkins DL (2000) 16S rDNA sequence analysis of Xylella fastidiosa strains. Syst Appl Microbiol 23:349-354

Cilia V, Lafay B, Christen R (1996) Sequence heterogeneities among 16S ribosomal RNA sequences, and their effect on phylogenetic analyses at the species level. Mol Biol Evol 13:451-461

Clayton RA, Sutton G, Hinkle PS Jr, Bult C, Fields C (1995) Intraspecfic variation in small-subunit rRNA sequences in GenBank: why single sequences may not adequately represent prokaryotic taxa. Int J Syst Bacteriol 45:595-599

Cook M, Lynch WH (1999) A sensitive nested reverse transcriptase PCR assay to detect viable cells of the fish pathogen Renibacterium salmoninarum in Atlantic salmon (Salmo salar L.). Appl Environ Microbiol 65:3042-3047

Eckhart L, Bach J, Ban J, Tschachler E (2000) Melanin binds reversibly to thermostable DNA polymerase and inhibits Its activity. Biochem Biophys Res Comm 271:726-730

Elliott DG, Pascho RJ, Jackson LM, Matthews GM, Harmon JR (1997) Renibacterium salmoninarum in spring-summer chinook salmon smolts at dams on the Columbia and Snake Rivers. J Aquat Anim Health 9:114-126

Figueras MJ, Guarro J, Martínez-Murcia A (2000) Use of restriction fragment length polymorphism of the PCRamplified 16S rRNA gene for the identification of Aeromonas spp. J Clin Microbiol 38:2023-2025

Gibello A, Blanco MM, Moreno MA, Cutuli MT, Domenech A, 
Domínguez L, Fernández-Garayzábal JF (1999) Development of a PCR assay for detection of Yersinia ruckeri in tissues of inoculated and naturally infected trout. Appl Environ Microbiol 65:346-350

Graf J (1999) Diverse restriction fragment length polymorphism patterns of the PCR-amplified 16S rRNA genes in Aeromonas veronii strains and possible misidentification of Aeromonas species. J Clin Microbiol 37:3194-3197

Gustafson CE, Thomas CJ, Trust TJ (1992) Detection of Aeromonas salmonicida from fish by using polymerase chain reaction amplification of the virulence surface array protein gene. Appl Environ Microbiol 58:3816-3825

Hirono I, Masuda T, Aoki T (1996) Cloning and detection of the hemolysin gene of Vibrio anguillarum. Microb Pathog 21:173-182

Høie S, Heum M, Thoresen OF (1997) Evaluation of a polymerase chain reaction-based assay for the detection of Aeromonas salmonicida ss salmonicida in Atlantic salmon Salmo salar. Dis Aquat Org 30:27-35

Jacobs JA, Schot CS, Schouls LM (2000) The Streptococcus anginosus species comprises five 16S rRNA ribogroups with different phenotyptic characteristics and clinical relevance. Int J Syst Microbiol 50:1073-1079

Knibb W, Colorni A, Ankaoua M, Lindell D, Diamant A, Gordin H (1993) Detection and identification of a pathogenic marine mycobacterium from the European seabass Dicentrarchus labrax using polymerase chain reaction and direct sequencing for 16S rDNA sequences. Mol Mar Biol Biotechnol 2:225-232

Liefting LW, Andersen MT, Beever RE, Gardner RC, Forster RLS (1996) Sequence heterogeneity in the two 16S rRNA genes of Phormium yellow leaf phytoplasma. Appl Environ Microbiol 62:3133-3139

Liu WT, Marsh TL, Cheng H, Forney LJ (1997) Characterization of microbial diversity by determining terminal restric-

Editorial responsibility: Carey Cunningham,

Aberdeen, Scotland, UK tion fragment length polymorphisms of genes encoding 16S rRNA. Appl Environ Microbiol 63:4516-4522

Marshall S, Heath S, Henríquez V, Orrego C (1998) Minimally invasive detection of Piscirickettsia salmonis in cultivated salmonids via the PCR. Appl Environ Microbiol 64: 3066-3069

McIntosh D, Meaden PG, and Austin B (1996) A simplified PCR-based method for the detection of Renibacterium salmoninarum utilizing preparations of rainbow trout (Oncorhynchus mykiss, Walbaum) lymphocytes. Appl Environ Microbiol 62:3929-3932

Mylvaganam S, Dennis PP (1992) Sequence heterogeneity between the two genes encoding 16S rRNA from the halophilic archaebacterium Haloarcula marismortui. Genetics 130:399-410

Reischl U, Feldmann K, Naumann L, Gaugler BJM, Ninet B, Hirschel B, Emler S (1998) 16S rRNA sequence diversity in Mycobacterium celatum strains caused by presence of two different copies of 16S rRNA gene. J Clin Microbiol 36:1761-1764

Rhodes LD, Nilsson WB, Strom MS (1998) Sensitive detection of Renibacterium salmoninarum in whole fry, blood, and other tissues of Pacific salmon by reverse transcriptionpolymerase chain reaction. Mol Mar Biol Biotech 7:270-279

Van de Peer Y, Chapelle S, De Wachter R (1996) A quantitative map of nucleotide substitution rates in bacterial rRNA. Nucleic Acids Res 24:3381-3391

Wiik R, Stackebrandt E, Valle O, Daae FL, Rødseth OM, Andersen K (1995) Classification of fish-pathogenic vibrios based on comparative 16S rRNA analysis. Int J Syst Bacteriol 45:421-428

Yap WH, Zhang Z, Wang Y (1999) Distinct types of rRNA operons exist in the genome of the Actinomycete Thermomonospora chromogena and evidence for horizontal transfer of an entire rRNA operon. J Bacteriol 181:5201-5209

Submitted: May 31, 2001; Accepted: August 29, 2001

Proofs received from author(s): March 14, 2002 